\title{
Validity of Animal Ecology Practical Guide Based on Contextual Teaching and Learning (CTL) for Student
}

\author{
Asti $^{1 *}$, Trisna Putri ${ }^{1}$, Ratnawulan $^{1}$, Putri $^{1}$, Dwo Hilda ${ }^{1}$ \\ ${ }^{1}$ Biology Education of Postgraduate Program, Faculty of Natural Sciences and Mathematics, Universitas Negeri Padang, Indonesia \\ *Corresponding author.Email: nhanaasti@gmail.com; dwi hildaputri@yahoo.com
}

\begin{abstract}
Every university must have learning outcomes. The learning outcome is a formulation of learning purposes that need to be achieved and be owned by all graduates. Learning outcomes in universities are regulated by Indonesian National Qualification Framework (INQF). Every university tries to realize the S1 graduates according to KKNI's qualification through several strategies. One of the strategies is trying to create meaningful learning in every subject, for example in animal ecology. Meaningful learning in animal ecology subject can be obtained through the application of the CTL approach. Animal ecology subject is done at the class and lab work. in addition, Practical cannot be separated from the existence of practical guides. Based on the results of observation, it was known that the practical guide used has not applied all of CTL components. Therefore, development research needs to be conducted in order to produce a very valid practical guide based on CTL. Validity viewed by didactic, constructs and technical. The result of the research showed that the didactic aspect obtained $89,79 \%$ with very valid criteria, constructs aspect obtained $81,81 \%$ with very valid and technical aspect obtained $75,00 \%$ with valid criteria. Thus the animal ecology practical guide was suitable to be used by the student in the university.
\end{abstract}

\section{Keywords: Validity, Practical Guide, Animal Ecology, Contextual Teaching and Learning, Students}

\section{INTRODUCTION}

Education is the thing that every human being must have. One of the formal education in UU Republik Indonesia No.20 Tahun 2003 Pasal 1 [1] is an education in high education. Every high school strives to realize S1 graduates who are in accordance with INQF qualifications through various strategies. One of the college strategies is to improve the quality of the lecture process. Animal ecology is one of the compulsory subjects in the Biology Department.

The author has collected preliminary data from several universities in the city of Padang. Data were collected through interviews with several lecturers of animal ecology, giving questionnaires to students who had studied animal ecology, giving questionnaires to the practical assistant and syllabus analysis and practical guide.

The results of interviews with several lecturers of animal ecology showed that students who had low motivation, low craft levels, did not have a deep understanding of animal ecology material. Without high motivation in learning, students will have difficulty in facing various challenges of learning, as the result students are easily discouraged and only struggle for the title without gaining academic excellence [2].

In addition to the above constraints, the broad scope of animal ecological material tent to make students memorize rather than understand the material. This was reinforced by the results of student questionnaires which showed that the coverage of animal ecology material was extensive (55\%). The impact of this obstacle as a whole is that students had difficulty in building understanding and applying examples related to the material in their daily life.

The results of the questionnaire that were given to the students showed that some students had difficulty in studying animal ecology material. Some students had difficulty in understanding the concept $(35 \%)$ and some students stated that animal ecology material was rote $(60 \%)$. As a result, students increasingly had difficulty in building and understanding the next material, because the animal ecology material was intregated with each other.

One solution to overcome the obstacles in animal ecology lectures is to carry out lab work. Practical is a series of activities that enable students to apply their skills, test or realize theories that have been studied in the class [3]. Practical aims to help students build concepts and communicate various phenomena that occur in science [4]. In addition, practical also aims to improve students' understanding of the material that has been studied, because students are directly involved in learning [5].

Practical activity should use a practical guide thus the activities carried out become more systematic and scientific. The practical guide makes it easier for students to carry out practical work and compile lab reports. In line with that, practical guide is a tool to achieve learning goals and encourage students to be more active [6]. The conclusion of the interview with the practical guide showed that some students did not understand and interpret 
the practical that was carried out. This problem directly resulted in low ecological practical values.

Subsequent data collection was then carried out through analysis of the syllabus and guidance on animal ecology practical. The results of this analysis indicated that: 1) the components of practical activities in the practical guide used were not complete; 2) there was practical material that has not been appropriate with the material in the syllabus, and 3) there was material in the syllabus that could be practiced, but there was no activity on the guide used.

The shortcomings in the existing practical guide can be overcome by developing an ecological practical guide with a Contextual Teaching and Learning (CTL) approach. This development is expected to answer the shortcomings and create meaningful learning. CTL allows students to gain knowledge and experience [7]. The development of this practical guide in the long term is expected to help students to apply their knowledge in daily life, one of them is to get a job. Students as prospective teachers can explain to students how to interact and maintain ecosystem stability.

in order to find out whether it is suitable or not, the development of animal ecology practical guide needs to pass some tests. One of the tests is the validity test. Validity is an integral evaluative assessment to know how to extends the empirical evidence and theoretical reason that support compatibility of conclusion and action based on the scores or other measurement methods. In other words, validity is to what extends an instrument that measures what is needed to be measured [5]. A valid instrument is not only able to produce precise data, but also give an accurate image of the data. Accuracy means that the measurements can give an image of the difference between one subject with other subjects in detail.

The validity test is conducted to find out the validity of the instruments used. An instrument is valid when it can measure what is needed and reveal the data from variables accurately.

\section{LITERATURE STUDY}

\section{$2.1 \quad$ Validity}

Validity is a validity criterion or validity of the product that is produced. To produce a valid product, validation is required. Validation is an activity to assess product design rationally. it is said rational because this validation is an assessment based on rational thinking, not a fact in the field. The validity of a product is assessed by validators (experts) who are experienced in their fields [8]. The aspects that need to be validated according to [9] include content, design and technical quality. If these aspects are met, the product is declared valid. The validity test instrument that has been designed was given to the validator for assessment, correction, and advice. After completion, a prototype revision was carried out based on the validator's corrections and suggestions [10].

According to [11] validity consists of logical and empirical validity. Logical validity shows the condition for a teaching material that meets valid requirements based on the results of the study, while empirical validity if it has been tested from experience. Terms of preparation of practical guides according to [12] are a didactic, construction and technical requirement.

\subsection{Practical Guide}

Practical work will be more planned and structured if it is equipped with a practical guide. The practical guide is said to be a reference in practical implementation. Practical guides can marginalize the role of educators thus the students are creative in thinking, skilled and facilitating educators in carrying out teaching in the laboratory [13]. Practical guide components according to [14] included: a) introduction; b) purpose; c) tools and materials; d) procedures/steps of activities; e) results of observations; f) data analysis; and g) conclusions.

\subsection{Contextual Teaching and Learning (CTL)}

The CTL approach is an approach to encourage students to get used to building and applying their knowledge in life [15]. The CTL approach makes students far more responsive to their knowledge [16]. The CTL approach makes students more active in learning [17]. In addition, the CTL approach also invites students to create a relationship that expresses meaning and have the potential to make them interested in learning [18].

The CTL approach aims to educate students. The CTL approach helps students gain knowledge and skills that can be applied and transferred from a context of one problem to another [19]. In addition, the CTL approach also helps students connect what is known to what they will learn [20].

The CTL approach has certain characteristics in learning. Characteristics of CTL according to [19], including: 1) is cooperation between students and educators (cooperative); 2) mutual assistance between students and assistants; 3) enjoy full learning; 4) contextually integrated learning; 5) using multimedia and learning resources; 6) how to learn active students; 7) take and give; and 8) critical students and creative educators.

The CTL approach has several components. The CTL component is constructivism, inquiry, questioning, community learning, modeling, reflection and authentic assessment [21]. The use of the CTL approach on practical guides is expected to help students thus learning outcomes can be realized optimally because the foundation of CTL is building relationships, constructivism, and active learning.

\section{RESEARCH METHODS}

This research was a development research. In other words, it was called a design research, this term was used by Plomp. This development model consists of three phases. They are preliminary research phase, development or prototype phase, and assessment phase [9]. In the preliminary research phase, problems analysis, the student needs analysis, and practical guide and syllabus analysis were conducted to get a clear image of a product that will be developed. Next, in development or prototype phase, there were some steps that were done, they were prototype 
I, prototype II, prototype III, dan prototype IV. In the assessment phase, testing of animal ecology practical guide was done to the real classroom. In developing and creating prototype phase of animal ecology practical guide based on CTL, validity test was conducted to prototype II by testing it to some experts. The validation of animal ecology practical guide based on CTL was conducted by 4 (four) experts. Then, the result was used to make revision thus it has fulfilled the needs of users and been able to be applied in the real classroom.

Validity analysis used practical guide validity. The data were obtained from the analysis of data collection instruments, such as questionnaire that were filled by some experts. Data Analysis was begun by determining scores for each items. The determination scores were based on likert scale,it can be seen in the Table 1 below.

Table 1: Likert Scale of Categories and Scores of items Animal Ecology Practical Guide Based On CTL for Student Validity.

\begin{tabular}{|c|c|}
\hline Score & Category \\
\hline 4 & Very Agree (SS) \\
\hline 3 & Agree (S) \\
\hline 2 & Disagree (TS) \\
\hline 1 & Very Disagree (STS) \\
\hline
\end{tabular}

After that, scoring results were tabulated and percentaged by using the following formula. Percentage of Validity $=$ Score $/$ Max.Score $\mathrm{x} 100 \%$.

Based on the validity score that was obtained, assessment criteria of animal ecology practical guide based on CTL were determined, like in table 2 below.

Table 2: Validity Categories of Animal Ecology Practical Guide Based On CTL.

\begin{tabular}{|c|l|}
\hline Validity Score (\%) & Category \\
\hline $0-20$ & Invalid \\
\hline $21-40$ & Less Valid \\
\hline $41-60$ & Valid Enough \\
\hline $61-80$ & Valid \\
\hline $81-100$ & Very Valid \\
\hline
\end{tabular}

\section{RESULT}

The developed product was animal ecology practical guide based on CTL. This practical guide has 10 practical activities. Animal ecology practical guide based on CTL was a practical guide based on all CTL components. The CTL component included constructivism, inquiry, questioning, learning community, modeling, reflection, and authentic assessment. Each student will be guided to carry out meaningful learning activities, help students relate this subject with their daily lives, which improve their learning competencies [18]

Animal ecology practical guide based on CTL was validated by some experts. Aspect validity of this practical guide included didactic aspect, construct aspect, and technical aspect. The validators in this validity process were Mr. Dr. Ramadhan Sumarmin, M.Si and Dr. Jasmi, M.Si as a learning material expert, Mr. Dr.Abdurrahman,
M.Pd as a linguistic expert, and Mr. Dr. Darmansyah, S.T, M.Pd as a technology experts.

Table 3: Animal Ecology Practical Guide Validation Result by Experts.

\begin{tabular}{|c|c|c|}
\hline Assessment Aspect & Score & Criteria \\
\hline Didactic & $89,79 \%$ & Very valid \\
\hline Constructs & $81,81 \%$ & Very valid \\
\hline Technical & $75,00 \%$ & Valid \\
\hline Validity Score & $82,19 \%$ & Very valid \\
\hline
\end{tabular}

\section{DISCUSSION}

Didactic aspect on the animal ecology practical guide based on CTL had very valid criteria. Validity in the didactic aspect was obtained because practical guides were developed was in accordance with the material in the animal ecology syllabus. Practical activities that were carried out was in accordance with the purpose to be achieved. The summary of the material in the practical guide was in accordance with the practical needs and comes from scientific sources. The substance of the material in practical activities was easy to be understood. The components of CTL on the practical guide encouraged students to get meaningful learning because students were directly involved in their knowledge. This was in line with the statement of [22] who said that learning that connect between material and personal and social environment of students will create meaningful learning.

Learning based on CTL made students be active in learning. Every CTL component influences the learning. The components included: 1) constructivism, in the basic theory, described basic material that supports the practical, thus the students were able to build their own knowledge; 2) inquiry, students would find their knowledge through critical thinking processes (practical observation); 3) questioning, questions in the practical guide led students to concepts they need to understand; 4) learning community, students got their knowledge through an interaction process; 5) modeling, students were directed to provide examples of phenomena or situations in their environment related to the material being practiced; 6) reflection, students were asked to recall what they have learned, thus they can conclude their learning experience; and 7) authentic assessment, it was not only the assessment of the final result but also assessment in the learning process.

Constructs aspect of the animal ecology practical guide based on CTL had very valid criteria. The validity of the construction aspect was obtained because the animal ecology practical guide based on CTL were arranged systematically, concisely, and appropriately to Ejaan Bahasa Indonesia (EBI) and used clear sentences. This was emphasized by [23] clear and not too long sentences are needed in writing. Animal ecology practical guide based on CTL had several language revisions because errors still occur. The results of the validation of the construction aspect declared that animal ecology practical guide based on CTL developed has used good and correct Indonesian.

The technical aspect of the animal ecology practical guide based on CTL had valid criteria. The validity of 
technical requirements was obtained because the animal ecology practical guide based on CTL use fonts that had clear readability. The images or illustrations presented have attractive colors, quite large resolutions and were placed in the right position and in accordance with the material presented. The use of this exact image, of course, had a good influence on students as a practical guide user. This is in accordance with [24] who stated that images function is to clarify the concept of a material.

Images that support the material used colors that contrasted with the color of writing, while additional colors on the animal ecology practical guide based on CTL were made by using black gradation in order not to disturb the students focus when using animal ecology practical guide based on CTL. This is in line with the statement of [25] who revealed that in visual media emphasis is needed on one of the elements that are the center of attention.

Interesting media could stimulate students to study. According to [13] stimulus is all things that can stimulate the occurrence of learning activities such as thoughts, feelings or other things that can be captured by the senses. Therefore, the stimulus was important because it related to student acceptance of material that will direct them to read more material. The appearance of various image media, according to [25] can improve and direct the attention of students, giving rise to motivation to learn. The results of this technical condition validation stated that the developed animal ecology practical guide based on CTL has met the technical criteria.

\section{CONCLUSION}

Based on the research result and discussion, it could be concluded that animal ecology subject had been successful to be created in form of the practical guide based on Contextual Teaching and Learning (CTL). Animal ecology practical guide based on CTL could be used as innovation in the teaching-learning process. The developed animal ecology practical guide based on CTL had 'very valid' validity in didactic and construct aspect and 'valid' in the technical aspect. Therefore, Animal ecology practical guide based on CTL could be used in the teaching-learning process to help students in achieving basic competence to improve their learning competencies.

\section{ACKNOWLEDGMENTS}

Thanks to Mrs. Dr. Ratnawulan, M.Si and Ms. Dr. Dwi Hilda Putri, M.Biomed as advisors who have given motivation to the writer in writing this journal.

\section{REFERENCES}

[1] Undang-Undang No. 20 tahun 2003 Tentang Sistem Pendidikan Nasional. Jakarta: Depdiknas.2003. pp 2-21

[2] Hamjah, Salasiah Hanin, Zainab Ismail, Rosmawati Mohammad Rasit dan Ermy Azziaty Rozali. Methods of Increase Learning Motivation Among Students. Procedia Social and Behabioral Sciences. 2011.pp 20-34
[3] Subiantoro, Agung. Pentingnya Praktikum Dalam Pembelajaran IPA". Makalah disajikan dalam Pelatihan Pengembangan Praktikum IPA Berbasis Lingkungan bagi Guru-Guru MGMP IPA SMP Kota Yogyakarta. Yogyakarta. 2010.pp 55-56

[4] Salirawati, Das dkk. Pelatihan Pengembangan Praktikum IPA Berbasis Lingkungan. INOTEK. 2011.pp 33-45

[5] Dirman dan Cicih Juarsih. Komunikasi Peserta Didik, PT Asdi Mahasatya. Jakarta. 2014.pp 10-23

[6] Umah, S.K., Sardiman dan Dewi N.R. Pengembangan Petunjuk Praktikum IPA Terpadu Berbasis Inkuiri Terbimbing pada Tema Makanan dan Kesehatan. Unnes Science Education Journal. Vol 2 No 3, pp 10-10, 2014.

[7] [7] Selvianiresa dan Prabawanto. Contextual Teaching and Learning Approach of Mathemathic in Primary Schools. Internasional Conference on Mathemathic and Science Education (ICMScE). 2017.pp 112-118

[8] [8] Sugiyono. Metode Penelitian Pendidikan: Pendekatan Kuantitatif, Kualitatif dan R\&D, Alfabeta. Bandung. 2012.pp 50-65

[9] [9] Plomp, T dan N, Nieveen (Eds.). Educational Design Research: An Introduction, Netherlands Institute for Curriculum Development. Netherlnds. 2013.pp 70-89

[10][10] Lufri dan Ardi. Buku Ajar Metodologi Penelitian, UNP Press. Padang. 2014.pp 20-34

[11][11] Arikunto, Suharsimi. Dasar-Dasar Evaluasi Pendidikan, Bumi Aksara. Jakarta. 2012. pp 4044

[12][12] Widjajanti, E. "Pelatihan Penyusunan LKS Mata Pelajaran Kimia Berdasarkan KTSP Bagi Guru SMK/ MAK“. Makalah disajikan dalam Kegiatan Pengabdian pada Masyarakat, Yogyakarta, 22 Agustus 2008. 2008.pp 2-11

[13][13] Arifah, Isnaini, Arif Maftukhin dan Siska Desi Fatmaryanti. Pengembangan Buku Petunjuk Praktikum Berbasis Guided Inquiry untuk Mengoptimalkan Hands On Mahasiswa Semester II Program Studi Pendidikan Fisika Universitas Muhammadiyah Purwerejo Tahun Akademik 2013/2014. Jurnal Radiasi. 2014. pp 21-30

[14][14] Wayan, I.. Standar Nasional Pendidikan, AzZahra Book's. Jakarta. 2010.pp 12-23

[15][15] Berns, Robert G dan Patricia M Erickson. Contentextual Teaching and Learning: Preparing Students for the New Economy. Educational Resources Information Center (ERIC). 2001.pp 45-64

[16][16] Smith, Bettye P. Instructional Strategies in Family and Consumer Sciences: Implementing the Contextual Teaching and Learning Pedagogical Model. Jounal of Family \& Consumer Sciences Education. 2010. 
[17][17] Surdin. The Effect of Contextual Teaching and Learning (CTL), Models on Learning Outcomes of Social Science of the Material of Forms the Face of the Earth on Class VII of Junior High School. Internasional Journal of Education and Research. Vol 2 No 2. pp10-18 June 2018.

[18] [18] Johnson, Elaine B. Contextual Teaching and Learning: Menjadikan Kegiatan Belajar-Mengajar Mengasyikkan dan Bermakna, Kaifa. Bandung. 2014.pp 45-55.

[19] [19] Hanafiah dan Cucu Suhana. Konsep Strategi Pembelajaran, Refika Aditama. Bandung. 2012.pp 32-40.

[20][20] Hudson, Clemente Charles. Contextual Teaching and Learning for Practitioer. Systematics, Cybernetics and Informatics. 2007.pp 88-93.

[21][21] Sanjaya, Wina. Pembelajaran Dalam Implementasi Kurikulum Berbasis Kompetensi, Kencana. Jakarta. 2005.pp 33-56.

[22][22] Sears, Susan. Contextual teaching and Learning. A Primer for Effective Instruction, Phi Delta Kappa Educational Foundation. USA. 2002.pp 70-88

[23][23] Depdiknas. Panduan Pengembangan Bahan Ajar, Direktorat Jendral Manajemen Pendidikan Dasar dan Menengah. Jakarta. 2008.pp 41-51

[24][24] Rohani. Pengelolaan Pengajaran, PT. Asdi Mahasatya. Jakarta. 2010.pp 67-87

[25][25] Arsyad, A. Media Pembelajaran, Rajawali Pers. Jakarta. 2009.pp 21-32. 